\title{
Exploiting Epigenetic Variations for Crop Disease Resistance Improvement
}

\author{
Pengfei Zhi and Cheng Chang* \\ College of Life Sciences, Qingdao University, Qingdao, China
}

Pathogen infections seriously threaten plant health and global crop production. Epigenetic processes such as DNA methylation, histone post-translational modifications, chromatin assembly and remodeling play important roles in transcriptional regulation of plant defense responses and could provide a new direction to drive breeding strategies for crop disease resistance improvement. Although past decades have seen unprecedented proceedings in understanding the epigenetic mechanism of plant defense response, most of these advances were derived from studies in model plants like Arabidopsis. In this review, we highlighted the recent epigenetic studies on crop-pathogen interactions and discussed the potentials, challenges, and strategies in exploiting epigenetic variations for crop disease resistance improvement.

OPEN ACCESS

Edited by:

Khalid Amari,

Julius Kühn-Institute, Germany

Reviewed by:

Athanasios Dalakouras, Hellenic Agricultural Organization -

ELGO, Greece

Ming-Bo Wang,

Commonwealth Scientific and Industrial Research Organisation (CSIRO), Australia

*Correspondence: Cheng Chang cc@qdu.edu.cn

Specialty section: This article was submitted to

Plant Cell Biology,

a section of the journal

Frontiers in Plant Science

Received: 08 April 2021

Accepted: 27 April 2021

Published: 04 June 2021

Citation:

Zhi P and Chang C (2021) Exploiting Epigenetic Variations for Crop Disease Resistance Improvement

Front. Plant Sci. 12:692328.

doi: 10.3389/fp/s.2021.692328
Keywords: disease resistance, crop breeding, epigenetic variation, defense priming, DNA methylation, histone modification, chromatin assembly and remodeling, epigenetic memory

\section{INTRODUCTION}

The dense monoculture of domesticated crops usually enhances the production value of cultivated land in intensive agriculture (Bruce, 2012). However, crop plants in these monocultures are particularly vulnerable to plant diseases caused by host-adapted pathogens. Therefore, developing disease-resistant crop varieties is essential to secure and enhance crop production in sustainable agriculture (Nicaise, 2017; Oliva and Quibod, 2017; Silva et al., 2018). To this end, it is vital to decipher the molecular mechanism underlying the plant host-pathogen interactions. During the long-term co-evolution with host-adapted pathogens, plants have acquired a sophisticated induced defense system to cope with pathogen infections (van der Burgh and Joosten, 2019; Zhou and Zhang, 2020). Recognition of pathogen-associated molecular patterns (PAMPs) or damage-associated molecular patterns (DAMPs) by plant pattern recognition receptors (PRRs) activates the pattern-triggered immunity (PTI), whereas detection of pathogen-secreted effectors by plant resistance (R) proteins initiates the effector-triggered immunity (ETI) (Couto and Zipfel, 2016; Jones et al., 2016; Li et al., 2016; Yu et al., 2017; Saijo et al., 2018). Although PTI and ETI differ in the magnitude and duration of downstream defense responses, they are mutually potentiated in the unified plant immunity and both associated with a massive transcriptional reprogramming of defense-related genes (Birkenbihl et al., 2017; Adachi and Tsuda, 2019; Bjornson et al., 2021; Ngou et al., 2021; Pruitt et al., 2021; Yuan et al., 2021). Increasing evidence revealed that epigenetic processes such as DNA methylation, histone post-translational modifications, chromatin assembly and remodeling govern this defense-related transcriptional reprogramming and play key roles in the regulation of crop disease resistance against a wide range of phytopathogens, including viruses, bacteria, fungi, oomycetes, netamodes, and herbivorous insects (Ding and Wang, 2015; Espinas et al., 2016; Zhu et al., 2016; Ramirez-Prado et al., 2018a,b; Wang C. et al., 2018; Alonso et al., 2019). 


\section{DNA (DE)METHYLATION DYNAMICS AND ITS BIOLOGICAL RELEVANCE IN CROP-PATHOGEN INTERACTIONS}

As a heritable epigenetic mark, DNA methylation usually occurs at the $\mathrm{C} 5$ position of cytosine base in the context of $\mathrm{CG}$, $\mathrm{CHG}$, and $\mathrm{CHH}(\mathrm{H}=\mathrm{A}, \mathrm{C}$, and $\mathrm{T})$ to form 5-methylcytosine $(5 \mathrm{mC})$, and plays important roles in the regulation of plant development, stress adaptation and genome evolution (Colot and Rossignol, 1999; Tirnaz and Jacqueline, 2019). A recent study in liverwort Marchantia polymorpha, an early-diverging terrestrial plant lineage, revealed that the extensive N4 cytosine methylation is essential to Marchantia spermatogenesis, further expanding the scope of functional DNA methylation in plants (Walker et al., 2021). In general, DNA methylation profile is dynamically shaped by three processes involving de novo methylation, maintenance methylation, and active demethylation (Henderson and Jacobsen, 2007). De novo methylation is triggered by small RNAs via an RNA-dependent DNA methylation (RdDM) process regulated by the Domains Rearranged Methyltranferase 2 (DRM2) (Erdmann and Picard, 2020). Once established, DNA methylation could be either maintained by methyltransferase1 (MET1) and plantspecific chromomethylases (CMT2 and CMT3), or removed by DNA demethylases, including Repressor of Silencing 1 (ROS1), Demeter (DME), Demeter-Like 2 (DML2), and DML3 in Arabidopsis (Elhamamsy, 2016). Detailed mechanisms of DNA methylation and demethylation have been extensively discussed by prior reviews (Chan et al., 2005; Law and Jacobsen, 2010; Elhamamsy, 2016).

With the contribution of DNA (de)methylation mutants and advanced DNA methylation profiling techniques such as methylation-sensitive amplified fragment length polymorphism (MSAP) analysis, whole-genome bisulfite sequencing (WGBS), methylated DNA immunoprecipitation sequencing (MeDIPseq), and methyl-CpG binding domain protein capture sequencing (MBDCap-seq), dynamics and biological functions of DNA (de)methylation in plant-pathogen interactions have been extensively studied in model and crop plants (Clark et al., 1994; Guevara et al., 2017; Li et al., 2018; Feng and Lou, 2019; Tirnaz and Jacqueline, 2019; Hsu et al., 2020). As a part of plant defense response, DNA hypomethylation is induced by pathogen infections in many plant species such as Arabidopsis thaliana, Oryza sativa, Nicotiana tabacum, Glycine max, Brassica rapa, Citrullus lanatus, and Aegilops tauschii (Dowen et al., 2012; Yu et al., 2013; Rambani et al., 2015; Kellenberger et al., 2016; López Sánchez et al., 2016; Wang C. et al., 2018; Geng et al., 2019; Sun et al., 2019; Atighi et al., 2020; Annacondia et al., 2021). A similar DNA hypomethylation is observed upon application of bacterial PAMP flg22, nematode PAMP "NemaWater," and plant defense hormone salicylic acid (SA) in model and crop plants (Ngom et al., 2017; Atighi et al., 2020). High-resolution DNA methylation profiling revealed that this pathogen-induced DNA hypomethylation occurs in many chromatin regions proximal to defense-related genes, including promoters, gene bodies, and nearby transposable elements (TEs) (Dowen et al., 2012; Yu et al., 2013; Rambani et al., 2015; Kellenberger et al.,
2016; López Sánchez et al., 2016; Ngom et al., 2017; Wang C. et al., 2018; Geng et al., 2019; Sun et al., 2019; Atighi et al., 2020; Annacondia et al., 2021). Although combined analysis of DNA methylation and gene expression revealed that this pathogen-induced DNA hypomethylation is generally correlated with transcriptional activation of proximal defense-related genes, specific regulation of defense-related gene transcription by nearby DNA hypomethylation varies among plant species and genes (Yu et al., 2013; López Sánchez et al., 2016; Geng et al., 2019; Atighi et al., 2020). For instance, chemical inhibition of DNA methylation at the promoters of rice resistance gene $X A 21 G$ could activate the $X A 21 G$ transcription and establish the rice resistance against bacterial blight $(\mathrm{BB})$ caused by Xanthomonas oryzae pv. oryzae (Xoo) (Akimoto et al., 2007). In contrast, the same chemical inhibition of DNA methylation at the promoters of rice blast disease-resistance gene $\mathrm{Pib}$ compromised the Pib transcription and rice resistance against blast disease (Li et al., 2011). In addition to regulating nearby defense genes in cis, DNA (de)methylation could also regulate distant defense genes in trans (Tirnaz and Jacqueline, 2019). For instance, an elegant DNA methylation and gene expression analysis in the Arabidopsis hyper/hypo-methylated mutants showed that only $15 \%$ of defense-related genes induced in hypo-methylated nrpe1 mutant and repressed in hyper-methylated ros 1 mutant were associated with a proximal TE and NRPE1- and/or ROS1-controlled DNA methylation, indicating the presence of both cis- and trans-regulation of defense-related gene transcription by DNA (de)methylation (López Sánchez et al., 2016).

In addition to these sequencing and in silico evidence, genetic studies also provide important implications for the involvement of DNA (de)methylation in plant defense response to pathogenic microbes (Yang et al., 2013; Annacondia et al., 2018; Diezma-Navas et al., 2019). In Arabidopsis, DNA hypomethylation mutant nrpe1, met1-3, and $d d c$ (drm1-2 drm2-2 cmt3-11) exhibited potentiated resistance against the biotrophic oomycete pathogen Hyaloperonospora arabidopsidis ( $\mathrm{Hpa}$ ) and hemibiotrophic bacterial pathogen Pseudomonas syringae pv. tomato DC3000 (Pst DC3000) but enhanced susceptibility against necrotrophic fungal pathogen Plectosphaerella cucumerina $(P c)$, whereas DNA hypermethylation mutant ros1-4 showed attenuated resistance against Pst DC3000 and Hpa but enhanced resistance against $P c$ (Dowen et al., 2012; Yu et al., 2013; López Sánchez et al., 2016). In Aegilops tauschii, knockdown of a DRM2 homolog by barley stripe mosaic virus (BSMV)-based virus-induced gene silencing (VIGS) enhanced plant resistance to the fungal pathogen Blumeria graminis f. sp. tritici $(B g t)$, the causal agent of wheat powdery mildew (Table 1, Geng et al., 2019). Increasing evidence revealed that DNA (de)methylation also gets involved in the regulation of plant defense response to pests and nematodes (Leonetti and Molinari, 2020). For instance, Arabidopsis mutant plants deficient in methylation of DNA and H3K9 ( kyp) showed increased resistance to the infestation of green peach aphid Myzus persicae (Annacondia et al., 2021). Similarily, rice RdDM and DDM1 mutants dcl3, ago4, drm2, and $d d m 1$ exhibited attenuated susceptibility to the infection of nematode Meloidogyne graminicola, confirming a central role of DNA (de)methylation in the regulation of plant defense against 
pathogenic microbes, pests, and nematodes (Table 1, Atighi et al., 2020). In addition, DNA (de)methylation was shown to orchestrate the action of allelic defense-related genes. For instance, expression of WRKY45-1, a susceptible allele of the rice transcription factor gene WRKY45, could generate a trans-acting TE-derived small interfering RNA, TE-siR815, to suppress the defense-related gene siR815 Target 1 (ST1) by inducing RdDM and abolished the rice blight resistance mediated by WRKY45-2, a resistant allelic WRKY45 (Table 1, Zhang et al., 2016). Similarly, DNA (de)methylation of two tandem miniature transposons (MITE1, MITE2) at the promoter of PigmS, a susceptible allele of the rice Pigm resistance genes, governs its transcription in a tissue-specific manner and thereby contributing to the balance of rice disease resistance and yield (Deng et al., 2017). These studies shed light on the important roles of DNA (de)methylation in the regulation of plant-pathogen interactions as well as its great potentials in crop disease resistance enhancement.

\section{HISTONE MODIFICATIONS AND THEIR MULTIFACETED FUNCTIONS IN CROP DISEASE RESISTANCE}

As important epigenetic mechanisms, histone posttranslational modifications (PTMs) such as acetylation, methylation, and ubiquitylation usually occur at the histone N-terminal tails and

TABLE 1 | Epigenetic processes and regulators involved in the crop-pathogen interactions.

\begin{tabular}{|c|c|c|c|c|c|}
\hline $\begin{array}{l}\text { Epigenetic } \\
\text { process } \\
\text { category }\end{array}$ & $\begin{array}{l}\text { Regulator } \\
\text { gene name }\end{array}$ & Gene product family & $\begin{array}{l}\text { Crop } \\
\text { species }\end{array}$ & $\begin{array}{l}\text { Involvement of gene product in crop- } \\
\text { pathogen interactions and evidence }\end{array}$ & References \\
\hline \multirow[t]{6}{*}{$\begin{array}{l}\text { DNA } \\
\text { (de)methylation }\end{array}$} & AeDRM2 & $\begin{array}{l}\text { DNA methyltranferase } \\
\text { functioning in De novo DNA } \\
\text { methylation }\end{array}$ & A. tauschii & $\begin{array}{l}\text { Knockdown of } A e D R M 2 \text { by BSMV-VIGS } \\
\text { enhanced resistance of } A \text {. tauschii to the fungal } \\
\text { pathogen Bgt. }\end{array}$ & Geng et al., 2019 \\
\hline & OsDCL3 & $\begin{array}{l}\text { Dicer-like endoribonuclease } \\
\text { functioning in RdDM pathway }\end{array}$ & O. sativa & $\begin{array}{l}\text { Infection of nematode } M . \text { graminicola was } \\
\text { decreased in Osdc/3a and Osdc/3b mutants } \\
\text { compared with the control. }\end{array}$ & Atighi et al., 2020 \\
\hline & OsAGO4 & $\begin{array}{l}\text { Argonaute protein functioning in } \\
\text { RdDM pathway }\end{array}$ & O. sativa & $\begin{array}{l}\text { Infection of M. graminicola was decreased in } \\
\text { Osago } 4 a / b \text { mutant compared with the control. }\end{array}$ & Atighi et al., 2020 \\
\hline & OsDRM2 & $\begin{array}{l}\text { DNA methyltranferase } \\
\text { functioning in De novo DNA } \\
\text { methylation }\end{array}$ & O. sativa & $\begin{array}{l}\text { Infection of } M . \text { graminicola was decreased in } \\
\text { Osdrm2 mutant compared with the control. }\end{array}$ & Atighi et al., 2020 \\
\hline & OsDDM1 & $\begin{array}{l}\text { A nucleosome-remodeling } \\
\text { protein functioning in } \\
\text { maintenance of DNA methylation }\end{array}$ & O. sativa & $\begin{array}{l}\text { Infection of } M . \text { graminicola was decreased in } \\
\text { Osddm1 mutant compared with the control. }\end{array}$ & Atighi et al., 2020 \\
\hline & $\begin{array}{l}\text { OSTE- } \\
\text { SiR815 }\end{array}$ & $\begin{array}{l}\text { Small interfering RNA functioning } \\
\text { in RdDM pathway }\end{array}$ & O. sativa & $\begin{array}{l}\text { OsTE-siR815 suppresses the defense-related } \\
\text { gene siR815 Target } 1 \text { (ST1) by RdDM and } \\
\text { abolished the rice blight resistance. }\end{array}$ & Zhang et al., 2016 \\
\hline \multirow[t]{6}{*}{$\begin{array}{l}\text { Histone } \\
\text { modifications }\end{array}$} & TaGCN5 & Histone acetyltransferase & T. aestivum & $\begin{array}{l}\text { TaGCN5 activates wheat cuticular wax } \\
\text { biosynthesis required for triggering Bgt conidial } \\
\text { germination. }\end{array}$ & Kong et al., 2020b \\
\hline & OsHDT701 & Histone deacetylase & O. sativa & $\begin{array}{l}\text { OsHDT701 interacts with the rice RNase P } \\
\text { subunit Rpp30 and negatively regulates rice } \\
\text { defense responses to the fungal pathogen } M \text {. } \\
\text { oryzae and bacterial pathogen Xoo by } \\
\text { mediating histone deacetylation at PRR and } \\
\text { defense genes. }\end{array}$ & $\begin{array}{l}\text { Ding et al., } 2012 \text {; } \\
\text { Li et al., } 2021\end{array}$ \\
\hline & TaHDA6 & Histone deacetylase & T. aestivum & $\begin{array}{l}\text { TaHDA6 functions in concert with WD40-repeat } \\
\text { protein TaHOS15 and another HDAC } \\
\text { TaHDT701 to suppress wheat defense } \\
\text { responses to Bgt by reducing levels of histone } \\
\text { acetylation at defense-related genes. }\end{array}$ & $\begin{array}{l}\text { Liu et al., 2019; } \\
\text { Zhi et al., } 2020\end{array}$ \\
\hline & TaSRT1 & Histone deacetylase & T. aestivum & $\begin{array}{l}\text { Silencing TaSRT1 by FoMV-VIGS significantly } \\
\text { reduced CWMV infection in bead wheat. }\end{array}$ & Jin et al., 2020 \\
\hline & OsJMJ704 & Histone demethylase & O. sativa & $\begin{array}{l}\text { JMJ704 represses transcription of the rice } \\
\text { defense negative regulator genes and positively } \\
\text { regulates rice defense response against Xoo } \\
\text { infection. }\end{array}$ & Hou et al., 2015 \\
\hline & OsBRHIS1 & $\begin{array}{l}\text { Monoubiquitinated histone } \\
\text { binding protein }\end{array}$ & O. sativa & $\begin{array}{l}\text { BRHIS1 represses the expression of some } \\
\text { disease defense-related genes and rice blast } \\
\text { resistance through interating with } \\
\text { monoubiquitinated histone variants. }\end{array}$ & LiX. et al., 2015 \\
\hline $\begin{array}{l}\text { Chromatin } \\
\text { assembly and } \\
\text { remodeling }\end{array}$ & TaCHR729 & Chromatin remodeling factor & T. aestivum & $\begin{array}{l}\text { TaCHR729 activates wheat cuticular wax } \\
\text { biosynthesis required for triggering Bgt conidial } \\
\text { germination. }\end{array}$ & $\begin{array}{l}\text { Wang X. et al., } \\
2019\end{array}$ \\
\hline
\end{tabular}


get involved in the regulation of chromatin structures and functions (Ding and Wang, 2015; Ramirez-Prado et al., 2018a,b; Alonso et al., 2019; Wang C. et al., 2019). As a reversible process, histone acetylation is dynamically regulated by histone acetyltransferases (HATs) and histone deacetylases (HDACs) (Imhof and Wolffe, 1998). Generally, histone acetylation mediated by HATs could relax chromatin structure and facilitate gene transcription, whereas histone deacetylation mediated by HDACs contributes to gene repression (Song and Walley, 2016; Kong et al., 2020a). Exhaustive studies on Arabidopsis HATs (AtELP2 and AtELP3) and HDACs (AtHDA6, AtHDA19, AtSRT2, and AtHD2B) provide direct evidence for the involvement of histone (de)acetylation in the plant-pathogen interactions, which has been discussed in prior reviews (Kim et al., 2008; DeFraia et al., 2010; Defraia et al., 2013; Wang et al., 2010, 2015, 2017; Choi et al., 2012; Latrasse et al., 2017; RamirezPrado et al., 2018a,b). In addition, regulation of crop-pathogen interactions by histone (de)acetylation was supported by studies on the crop HATs and HDACs (Ding et al., 2012; Liu et al., 2019; Jin et al., 2020; Kong et al., 2020a; Zhi et al., 2020). For instance, wheat HAT complex TaGCN5-TaADA2 activates wheat wax biosynthesis by mediating histone acetylation at the promoters of biosynthesis-related genes, thereby providing wax signals for the conidial germination of fungal pathogen Bgt (Table 1, Kong et al., 2020b). Rice HDAC OsHDT701 interacts with the rice RNase $P$ subunit Rpp30 and negatively regulates rice defense responses to the fungal pathogen Magnaporthe oryzae (M. oryzae) and bacterial pathogen Xoo by mediating histone deacetylation at PRR and defense genes (Table 1, Ding et al., 2012; Li et al., 2021). Similarly, wheat HDAC TaHDA6, the ortholog of Arabidopsis AtHDA6, could function in concert with WD40-repeat protein TaHOS15 and another HDAC TaHDT701 to suppress wheat defense responses to the fungal pathogen Bgt by reducing levels of histone acetylation at defense-related genes (Table 1, Liu et al., 2019; Zhi et al., 2020). In addition, a recent genome-wide identification and expression analysis of the $H D A C$ gene family in bread wheat revealed that almost all TaHDACs were up-regulated by infection of the BSMV, Chinese wheat mosaic virus (CWMV), and wheat yellow mosaic virus (WYMV), suggesting their broad involvement in wheat defense response to viral infections (Jin et al., 2020). Significantly, silencing TaSRT1, a wheat HDAC gene, by Foxtail mosaic virus (FoMV)-based virus-induced gene silencing (VIGS) significantly reduced CWMV infection in bead wheat, indicating that TaSRT1 contributes to the wheat susceptibility to CWMV infection (Table 1, Jin et al., 2020). In addition to these studies on crop HATs and HDACs, functional characterization of effectors secreted by crop pathogens also sheds light on the importance of histone (de)acetylation in the regulation of crop-pathogen interactions (Kong et al., 2017; Walley et al., 2018; Wang C. et al., 2019). For instance, PsAvh23, an effector secreted by the soybean oomycete pathogen Phytophthora sojae, could bind to the ADA2 subunit of the HAT complex SAGA and disrupt its assembly, and subsequently repress the activation of defense genes by disturbing the HAT complex-mediated H3K9 acetylation, thereby enhancing soybean susceptibility to the P. sojae infection (Kong et al., 2017). Similarly, effector molecule HC-toxin (HCT), an HDAC inhibitor produced by the fungal pathogen Cochliobolus carbonum, was found able to modulate plant HDACs to alter acetylation of plant histones and nonhistone proteins (Walley et al., 2018). It is well-known that plants employ methylation-mediated transcriptional gene silencing as an effective defense system against geminiviruses infection (Wang B. et al., 2018). Notably, V2 protein of Tomato yellow leaf curl virus (TYLCV) could interact with host histone deacetylase 6 (NbHDA6) and interfere with the recruitment of MET1 by HDA6, thereby suppressing methylation-mediated transcriptional gene silencing (Wang B. et al., 2018). In addition to regulating crop defense responses, histone (de)acetylation is essential to the regulation of pathogen growth and infection (Chen et al., 2018; He et al., 2018). For instance, MoSNT2 protein of M. oryzae could recruit the histone deacetylase complex to promote the histone $\mathrm{H} 3$ deacetylation at the promoter of autophagy genes MoATG6, 15, 16, and 22, thereby regulating infection-associated autophagy (He et al., 2018). Another study revealed that wheat microbiome bacteria Pseudomonas piscium could secrete the compound phenazine1-carboxamide to directly interfere with the activity of fungal histone acetyltransferase FgGcn5 and reduce the virulence of wheat pathogenic fungus Fusarium graminearum by altering histone acetylation (Chen et al., 2018). These studies revealed that histone (de)acetylation get involved in the regulation of many processes, from pathogen growth and infection to plant defense responses, in crop-pathogen interactions and provide new opportunity to control crop diseases.

Analogous to histone acetylation, histone methylation is a dynamic and reversible process co-regulated by histone methyltransferases and demethylases (Black et al., 2012). Unlike histone acetylation generally correlated with gene activation, histone methylation is associated with both gene activation and repression. For instance, H3K4 methylation and H3K36 methylation are important for active transcription, whereas H3K9 methylation and H3K27 methylation contribute to gene repression (Ding and Wang, 2015; Ramirez-Prado et al., 2018a,b; Wang C. et al., 2019). As extensively discussed in previous reviews, three Arabidopsis histone methyltransferases (AtATX1, AtSDG8, and AtSDG25) and two histone demethylase (AtJMJ27 and AtIBM1) have been reported to directly regulate plant-pathogen interactions (Alvarez-Venegas et al., 2007; Berr et al., 2010; Lee et al., 2016; Dutta et al., 2017; Chan and Zimmerli, 2019; Zhang et al., 2020). In addition, increasing evidence supported that histone (de)methylation plays key role in regulating crop-pathogen interactions (Hou et al., 2015; Meller et al., 2018). For instance, spraying potato leaves with $\beta$-aminobutyric acid (BABA), a non-protein amino acid effective in improving plant disease resistance, could increase deposition of histone marks H3K4me2 and H3K27me3 on NPR1 and SNI1, regulatory genes in systemic acquired resistance (SAR), thereby reprogramming responsiveness of the defense-related genes (PR1 and PR2) and contributing to the potato intergenerational resistance to $P$. infestans (Meller et al., 2018). Jumonji C (JmjC) domain-containing proteins generally function as histone lysine demethylases. Genomewide identification and expression analysis of the rice $J m j C$ gene showed that expressions of $15 \mathrm{JmjCs}$ were induced by 
infection of bacterial blight pathogen Xoo. Further studies revealed that JMJ704 represses transcription of the rice defense negative regulator genes such as $N R R, O s-11 N 3$, and OsWRKY 62 by reducing $\mathrm{H} 3 \mathrm{~K} 4 \mathrm{me} 2 / 3$ at promoters of these genes, thereby potentiating rice defense response against Xoo infection (Table 1, Hou et al., 2015).

Although less explored compared with histone acetylation and methylation, histone mono-ubiquitination primarily occurs on histone $\mathrm{H} 2 \mathrm{~A}$ and $\mathrm{H} 2 \mathrm{~B}$, and plays an important role in transcriptional regulation. In Arabidopsis, histone H2B monoubiquitination ( $\mathrm{H} 2 \mathrm{Bub} 1)$ is mediated by the ubiquitin ligases HUB1 and HUB2 (Dhawan et al., 2009; Hu et al., 2014; Zou et al., 2014; Zhao et al., 2020). Functional characterization of HUB1 and HUB2 revealed that H2Bub1 contributes to the Arabidopsis resistance against bacterial pathogen Pst DC3000 and fungal pathogen Verticillium dahliae $(V d)$ by potentiating transcription of resistance genes (SNC1 and RPP4) and modulating the dynamics of cortical microtubules (MTs) (Hu et al., 2014; Zou et al., 2014). Interestingly, HUB1 was revealed to interact with MED21, a subunit of the Arabidopsis Mediator, and positively regulates defense against necrotrophic fungal pathogens Botrytis cinerea and Alternaria brassicicola in Arabidopsis (Dhawan et al., 2009). In addition, a recent study demonstrated that HUB-mediated $\mathrm{H} 2 \mathrm{Bub} 1$ positively regulates the expression of the NADPH oxidase RbohD, a critical defense modulator, by enhancing the $\mathrm{H} 3 \mathrm{~K} 4 \mathrm{me} 3$ enrichment, indicating the complex interplays among histone mono-ubiquitination, methylation, and mediator complex in the regulation of plant defense responses (Zhao et al, 2020). In addition to HUBs, binding proteins of monoubiquitinated histone are also demonstrated to be involved in the regulation of plant defense response ( $\mathrm{Li} \mathrm{X}$. et al., 2015). For instance, the rice SWI/SNF2 ATPase BRHIS1-containing complex was found to repress the expression of some disease defense-related genes (OsPBZc and OsSIRK1), as well as rice blast resistance, through specific interaction with monoubiquitinated histone variants H2B.7 and H2A.Xa/H2A.Xb/H2A.3, in the absence of pathogen infection (Table 1, Li X. et al., 2015). Characterizing more HUBs and monoubiquitinated histone binding proteins in crops will improve our understanding of the multiple roles of histone mono-ubiquitination in regulating crop-pathogen interactions in future research.

\section{THE REGULATORY ROLES OF CHROMATIN ASSEMBLY AND REMODELING IN PLANT DISEASE RESISTANCE}

Chromatin structure is essential to the organization of plant genomes and is dynamically controlled by histones and a wide range of modulators. In the regulation of gene transcription, chromatin structure governs the DNA accessibility to transcription machinery and plays a vital role in transcriptional regulation ( $\mathrm{Li}$ et al., 2007). Increasing evidence revealed that chromatin structure gets involved in the regulation of plant defense responses (Walley et al., 2008; Johnson et al.,
2015; Mozgová et al., 2015; Muñoz-Viana et al., 2017; Wang C. et al., 2019; Yang et al., 2019). For instance, knockdown of histone $\mathrm{H} 2 \mathrm{~B}$ in Nicotiana benthamiana using Tobacco rattle virus (TRV)-based virus-induced gene silencing (VIGS) resulted in the up-regulation of SA biosynthesis/signalingrelated genes such as EDS1, ICS1, and NPR1, leading to the increased endogenous SA accumulation and enhanced resistance against potato virus X (PVX) infection (Yang et al., 2019). CHROMATIN ASSEMBLY FACTOR 1 (CAF-1) is an evolutionarily conserved histone chaperone essential for post-replicative de novo assembly of histones into nucleosomes (Mozgová et al., 2015; Muñoz-Viana et al., 2017). In Arabidopsis, the absence of CAF-1 resulted in the reduced nucleosome occupancy and high $\mathrm{H} 3 \mathrm{~K} 4 \mathrm{me} 3$ at defense response genes PR1, $P R 5$, WRKY6, and WRKY53, leading to spurious activation of SA-dependent defense response in plants grown under standard non-sterile growth conditions, further confirming the repressive role of chromatin assembly in the transcription of defense-related genes (Mozgová et al., 2015; Muñoz-Viana et al., 2017).

In addition to histone $\mathrm{H} 2 \mathrm{~B}$ and histone chaperon $\mathrm{CAF}-1$, chromatin remodeling factors that could use the energy from ATP hydrolysis to disrupt the DNA-histone association also get involved in the regulation of plant defense responses (Walley et al., 2008; Johnson et al., 2015; Berriri et al., 2016; Wang C. et al., 2019; Huang et al., 2021). For instance, SWI/SNF chromatin remodeling protein SYD (SPLAYED) was revealed to negatively regulate the transcription of Arabidopsis R gene SNC1 and suppress the SNC1-mediated resistance to the bacterial pathogen Pseudomonas syringae pv. maculicola ES4326 (Walley et al., 2008; Johnson et al., 2015). SWP73A, an Arabidopsis ortholog of the mammalian SWI/SNF chromatin remodeling protein BAF60, was found to directly bind to the promoters of resistance genes RPS2 and RPS4 and suppress their expressions (Huang et al., 2021). In addition, SWP73A could suppress the transcription of RNA splicing regulator gene CDC5 and affect the alternative splicing of RPS2 and RPS4, thereby suppressing Arabidopsis defense responses (Huang et al., 2021). Interestingly, although SWR1 chromatin-remodeling complex (SWR1c) catalyzes the replacement of histone $\mathrm{H} 2 \mathrm{~A}$ by the histone variant $\mathrm{H} 2 \mathrm{~A} . \mathrm{Z}$ in nucleosomes in eukaryotic gene regulation, SWR1c subunits and H2A.Z were revealed to have non-overlapping functions in plant immunity and gene regulation (Berriri et al., 2016). At the same time, the regulation of crop disease resistance by chromatin remodeling proteins was supported by emerging evidence (Wang X. et al., 2019). For instance, the wheat CHD3type chromatin remodeling protein TaCHR729 was reported to bind to the promoter regions of wheat wax biosynthesis genes 3KETOACYL-CoA SYNTHASE (TaKCS6), and positively regulate the TaKCS6 transcription by enhancing the permissive epigenetic mark H3K4me3 at the promoter region of TaKCS6. Silencing of TaCHR729 by BSMV-VIGS could down-regulate the wheat wax biosynthesis and reduce conidial germination of Bgt, suggesting that the chromatin remodeling factors TaCHR729 contributes to the wheat-powdery mildew interaction through epigenetic activation of wheat cuticular wax biosynthesis (Table 1, Wang X. et al., 2019). 


\section{INVOLVEMENT OF EPIGENETIC MEMORY IN DEFENSE PRIMING}

In crop protection, treatment of crop plants with plant pathogens or priming agents such as salicylic acid (SA), acibenzolar S-methyl (BTH), $\beta$-aminobutyric acid (BABA), methyl-jasmonic acid (MeJA), pipecolic acid (Pip), and azelaic acid (AzA) could lead to a primed state of defense responses, as well as systemic acquired resistance (SAR), to future pathogen challenges (Reimer-Michalski and Conrath, 2016; Mauch-Mani et al., 2017). These defense priming and SAR could be sustained over generations (Jaskiewicz et al., 2011; Luna et al., 2012; Slaughter et al., 2012; Iwasaki and Paszkowski, 2014). For instance, treatment of common bean (Phaseolus vulgaris L.) with priming agent BABA could enhance plant disease resistance against the bacterial pathogen Pseudomonas syringae pv. Phaseolicola (Ramírez-Carrasco et al., 2017). Notably, expression of the defense-related PvPR1 gene (Phaseolus vulgaris PR1, the common bean ortholog of Arabidopsis PR1-1) exhibited a priming response against pathogen infections for at least two generations (Ramírez-Carrasco et al., 2017). In addition, epigenetic profiling revealed that this defense priming is generally associated with DNA methylation and histone modifications (Lämke and Bäurle, 2017; He and Li, 2018). For instance, treatment of Arabidopsis leaves with SA synthetic analog BTH or bacterial pathogen Pseudomonas syringae pv. Maculicola could induce enhancement of permissive epigenetic mark H3K4me2/3 on defense gene promoters, which is supposed to prepare chromatins for rapid activation of defense genes upon pathogen re-infections (Slaughter et al., 2012). Similarly, defense priming induced by MeJA in rice could enhance the levels of H3K4me3 and $\mathrm{H} 3 \mathrm{~K} 9 \mathrm{ac}$ at the promoters of defense-related gene OsBBPI, and affect the genome-wide DNA methylation $(5 \mathrm{mC})$ levels, leading to a chromatin-based memory of wounding stress (Laura et al., 2018).

Increasing evidence revealed that DNA methylation and histone modifications get involved in transgenerational defense priming (Slaughter et al., 2012; He and Li, 2018; Stassen et al., 2018; Sharrock and Sun, 2020). For instance, SAR induced by bacterial pathogen PstDC3000 could be inherited to generate progeny (P1) exhibiting potentiated expression of SA-inducible defense-related genes such as PR1, WRKY6, and WRKY53, as well as enhanced resistance against hemibiotrophic bacterial pathogen PstDC3000 and biotrophic oomycete pathogen Hpa (Luna et al., 2012; Slaughter et al., 2012). At the same time, these P1 progeny exhibited reduced expression of JAinducible defense-related genes such as PDF1.2 and VSP2, as well as decreased resistance against necrotrophic fungal pathogen Alternaria brassicicola (Luna et al., 2012). Further studies revealed that this difference in the expression of SAand JA-inducible defense-related genes in P1 progeny was not caused by hormone level changes but associated with shifts in histone modifications $\mathrm{H} 3 \mathrm{~K} 27 \mathrm{me} 3$ and $\mathrm{H} 3 \mathrm{~K} 9 \mathrm{ac}$ at the promoters of these defense-related genes (Luna et al., 2012). In addition, priming with bacterial pathogen PstDC3000 resulted in DNA hypomethylation in Arabidopsis, and DNA hypomethylation mutant drm1drm2cmt3 could mimic this transgenerational
SAR phenotype, further confirming that this transgenerational defense priming in the systemic plant immune response is governed by DNA methylation and histone modifications (Luna et al., 2012).

\section{APPLICATION OF EPIGENETIC VARIATIONS IN CROP DISEASE RESISTANCE IMPROVEMENT}

Intensive monoculture of domesticated crops on fertilized land increases the prevalence and incidence of plant diseases, which became severe under more frequent extreme weathers resulting from climate changes such as drought and heat weaves (Bruce, 2012; Cohen and Leach, 2020; Zytynska et al., 2020). Even with crop-protection strategies such as conventional chemical control and eco-friendly biological control, plant diseases account for approximately $20 \%$ global yield loss in important crops (Nicaise, 2017; Oliva and Quibod, 2017; Silva et al., 2018). Due to the rapid evolution of plant pathogens, classical breeding approaches for crop disease resistance improvement, which mainly rely on the exploitation of resistance $(\mathrm{R})$ genes, have become less effective (Rodriguez-Moreno et al., 2017). In addition, intensive artificial selection in the conventional breeding practices has eroded the genetic diversity of $\mathrm{R}$ genes (Rodriguez-Moreno et al., 2017). Cross-breeding crop varieties with their wild relatives and developing genetically modified organisms (GMOs) represent new promising approaches in crop resistance breeding (Bruce, 2012). As an alternative direction, epigenetic processes such as DNA methylation, histone modifications, chromatin assembly and remodeling could respond to pathogen infections and broaden phenotypic diversity suitable for crop resistance improvement. Therefore, epi-breeding referring to the genetic breeding for epigenetic changes provides new avenues for crop resistance improvement (Gallusci et al., 2017; Springer and Schmitz, 2017; Latutrie et al., 2019; Tirnaz and Batley, 2019; Varotto et al., 2020).

Both natural epigenetic diversity and artificially induced epigenetic variations could influence plant disease resistance and have great potentials in epi-breeding for crop resistance improvement. For instance, inheritable natural epialleles associated with plant development and stress adaptation have been characterized in some model and crop plants such as Arabidopsis, rice, oilseed rape, apple, tomato, and melon (Cubas et al., 1999; Manning et al., 2006; Martin et al., 2009; Long et al., 2011; Telias et al., 2011; Chen and Zhou, 2013; Liu et al., 2015; Latutrie et al., 2019). As discussed in the DNA (de)methylation section in detail, DNA hypomethylation was usually induced by biotic and abiotic stresses, suggesting that these stress conditions could be employed to induce disease-resistance-related epigenetic variations in crop plants. Furthermore, epigenetic variants could be experimentally obtained by chemicals treatments, mutations in epigenetic machinery, induced gene-specific DNA methylation, and epigenome editing (Gallusci et al., 2017; Springer and Schmitz, 2017; Latutrie et al., 2019; Tirnaz and Batley, 2019; Varotto et al., 
2020). For instance, 5-azacytidine and zebularine, two nonmethylable cytosine analogs, are widely used as inhibitor of DNA methyltransferases to chemically induce DNA demethylation (Baubec et al., 2009; Griffin et al., 2016). Although epigenetic changes induced by these stress conditions and chemical treatments are transient, alteration of epigenetic regulation could result in the mobilization of TE and formation of heritable epialleles, which could be employed for breeding purposes (Mirouze and Paszkowski, 2011). Through mutagenizing DNA (de)methylation machinery and crossing genetically identical plants with different DNA methylation levels, epigenetic recombinant inbred line (epiRIL) populations with similar genomic backgrounds but different DNA methylation levels at specific chromatin regions were successfully created in Arabidopsis, and these epiRIL populations displayed discernible phenotypic variations such as altered disease resistance (Zhang et al., 2018). However, creating epiRILs in crop plants such as bread wheat and maize has proved more challenging due to lack of DNA (de)methylation mutants, low genome stability, as well as low rates of transformation, regeneration and mutagenesis in crop plants (Kapazoglou et al., 2018).

Induced gene-specific DNA methylation and epigenome editing represent new promising approaches to generate epiallelic variations in model and crop plants. Indeed, 24nt short-interfering RNAs (siRNAs) generated by doublestranded RNAs (dsRNAs) could direct DNA methylation and induce transgenerationally heritable silencing of plant endogenous genes (Kasai and Kanazawa, 2013; Dalakouras and Papadopoulou, 2020). Notably, exogenous application of dsRNA designed to target gene promoter regions resulted into promoter RdDM, which could circumvent crop breeding obstacles such as low transformation and regeneration rate, thereby representing a novel methodology for crop epigenome modification (Dalakouras and Papadopoulou, 2020; Dalakouras and Ganopoulos, 2021). In mammalian cells, epigenome editings have been established through fusing an inactive variant of Cas9 (CRISPR associated protein 9), the most widely used sequencespecific nucleases (SSNs) in the CRISPR system (clustered regularly interspaced short palindromic repeat), to histone modifying enzymes such as histone demethylase LSD1, DNA methyltransferase DNMT3A and the catalytic core of the human histone acetyltransferase p300 (Hilton et al., 2015; Kearns et al., 2015; Kungulovski and Jeltsch, 2016; Vojta et al., 2016; Liu and Moschou, 2018). Similarly, Johnson et al. selectively targeted regions of Arabidopsis genomes for DNA methylation through fusing a zinc finger ( $\mathrm{ZF}$ ) peptide with the RdDM component SUVH9, which paves the path to the locus-specific epigenome editing in crop plants (Kolb et al., 2005; Johnson et al., 2014). However, to achieve a similar CRISPR or ZF-based epigenome editing in crop plants, it necessitates either stable transformation of crop plants with corresponding CRISPR or ZF elements or transfection of crop protoplasts with preassembled CRISPR or ZF complex, which is obstructed by low rates of transformation and regeneration in some crop plants such as bread wheat (Woo et al., 2015). In addition, placing crop products improved by epigenome modification techniques on the market also requires clarification and update on the current regulatory framework applied for GMOs and GEENs (genome editing using engineered endonuclease) in some countries (Metje-Sprink et al., 2019).

As important questions in epi-breeding, transmission features of epigenetic variations such as stability and inheritability should be discussed. It was widely demonstrated that differentially methylated regions (DMRs) in epialleles are transmitted in a Mendelian manner during meiosis, indicating that DNA methylation could function as a stable and heritable epigenetic mark over generations (Schmitz et al., 2013; Li Q. et al., 2015). As demonstrated by elegant studies in plant vernalization, histone modifications could be stably transmitted through mitosis (Baulcombe and Dean, 2014). For instance, enrichment of repressive epigenetic mark $\mathrm{H} 3 \mathrm{~K} 27 \mathrm{me} 3$ at the FLC locus, as well as the FLC silencing, induced upon cold exposure could be stably maintained during the rest life cycle of Arabidopsis (Coustham et al., 2012). Although the involvement of histone modifications in transgenerational stress memory has been supported by a few studies, the transgenerational inheritance of histone modifications is rather limited. For instance, vernalization involving $\mathrm{H} 3 \mathrm{~K} 27$ methylation is reset in each generation (Baulcombe and Dean, 2014). Therefore, histone modifications likely could not be stably transmitted during sexual reproduction.

Epi-breeding strategies for crop resistance improvement are determined by both transmission features of epigenetic variations and propagation types of crop plants (Gallusci et al., 2017; Latutrie et al., 2019). As epigenetic marks stably transmitted across plant generations, DNA methylation could be used in breeding crop plants propagated vegetatively or by seed. In contrast, histone modifications could not be transgenerationally inherited and are only suitable for breeding clonally propagated crops. As an efficient large-scale reproduction strategy, clonal propagation has an advantage in fixing beneficial epigenetic traits and is applicable for over $60 \%$ of crops, including potatoes, yams, taros, sorghums, and cassavas (Meyer et al., 2012; Latutrie et al., 2019). In addition, molecular epigenomic markers such as differentially methylated regions (DMRs) could be used for the early characterization of epigenetic states in meristem/seed screening and contributes to the marker-assisted selection in crop epi-breeding for disease resistance improvement (Gallusci et al., 2017; Latutrie et al., 2019).

Epigenetic modeling could predict the effect of epigenetic variations on plant phenotype and fill the gap between epigenetic variations and epi-breeding for disease resistance improvement (Gallusci et al., 2017). As discussed in prior reviews, a statistical model could be used to explore the linkage between DNA methylomes and transcriptomes without any knowledge on underlying mechanisms of biological processes, whereas a more advanced process-based model was developed to predict the effects of epigenetic variations on gene expression, as well as plant phenotypes, through employing equations defining the essence of well-studied biological processes (Richards et al., 2012; Buck-Sorlin, 2013; Gallusci et al., 2017). For instance, statistical models were employed to identify novel relationships between DNA methylation and gene expression in Mimulus guttatus and link DNA methylation information with plant 
height variances in A. thaliana (Colicchio et al., 2015; Hu et al., 2015). Similarly, process-based models were developed to link histone modifications, gene expression, and plant phenotypes such as vernalization and lycopene metabolism in Arabidopsis and tomato (Angel et al., 2011; Gallusci et al., 2017). Therefore, epigenetic modeling, especially the process-based model, could be used to investigate the effect of specific epigenetic variations on plant disease resistance and guide the decision to induce or suppress these epigenetic variations for resistance improvement in crop epi-breeding.

\section{气 $\begin{gathered}\text { Natural epigenetic } \\ \text { variations }\end{gathered}$ Induced epigenetic variations

\begin{tabular}{ll}
\multicolumn{1}{c}{ Variations } \\
$\qquad \begin{array}{l}\text { Natural epialleles } \\
\text { Identification through } \\
\text { genetic map-based } \\
\text { cloning and genome- } \\
\text { wide DNA methylation } \\
\text { profiling }\end{array}$ \\
을 & $\begin{array}{l}\text { Employment through } \\
\text { epiRILs construction and } \\
\text { recurrent epi-selection }\end{array}$ \\
\hline
\end{tabular}
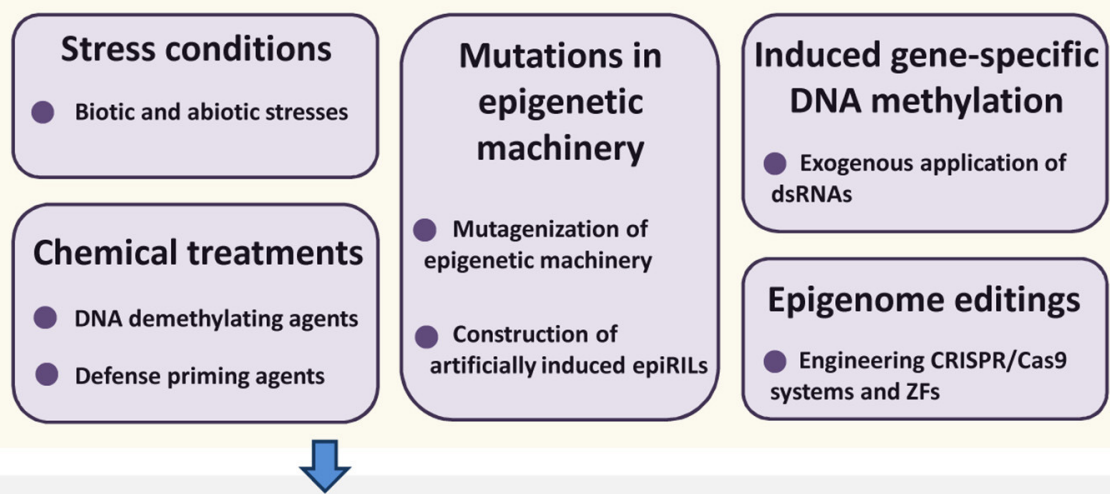

Crop populations with epigenetic and disease resistance variations
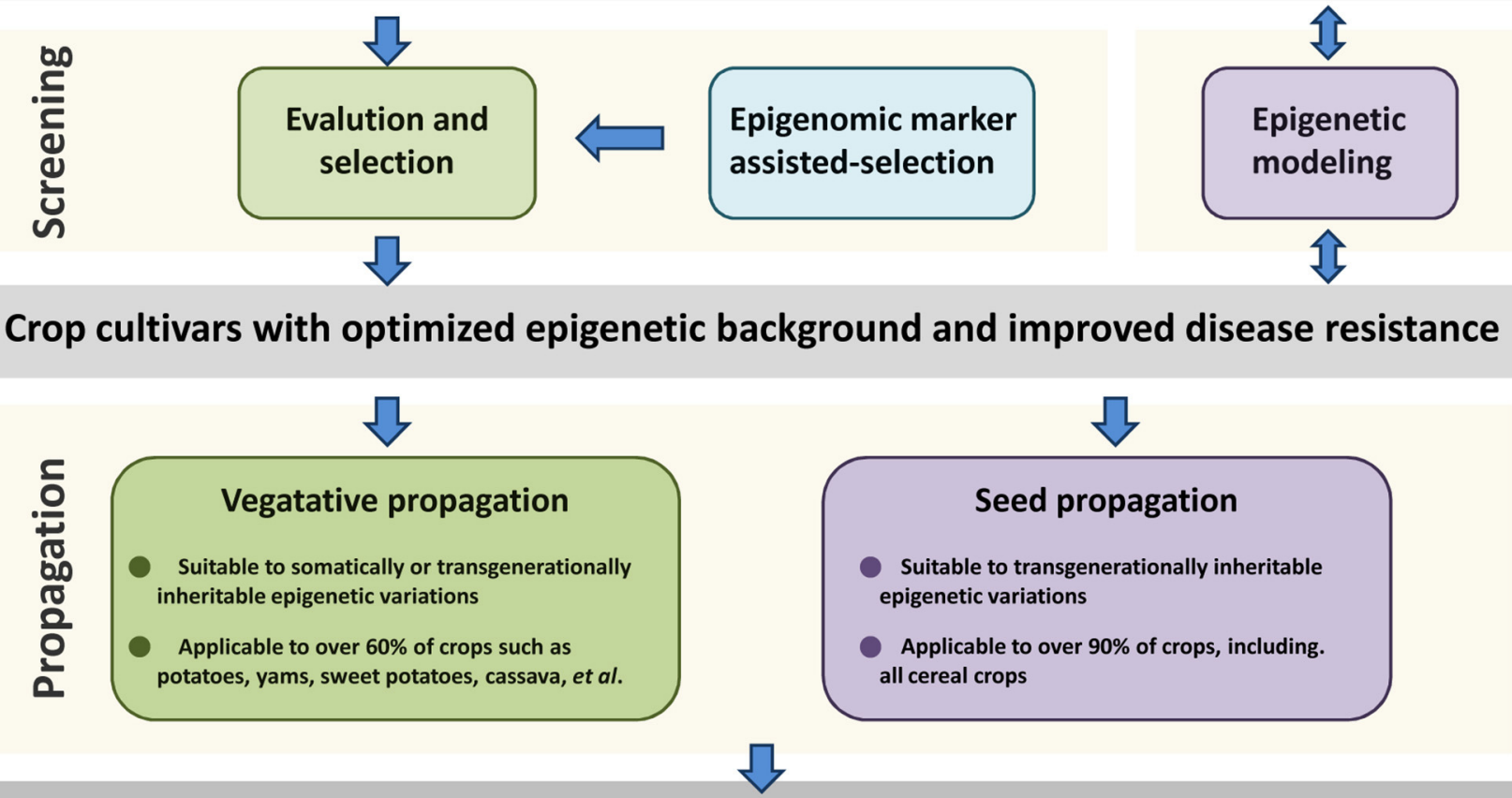

\section{Crop cultivation}

FIGURE 1 | Epi-breeding design for crop disease resistance improvement. Epigenetic variations are either derived from natural populations, or induced by stresses, chemical treatments, mutations in epigenetic machinery, induced gene-specific DNA methylation, and epigenome editings. After epigenetic variations have been generated, crop variants with improved disease resistance are chosen and propagated. DNA methylation marks can be transgenerationally inherited and suitable for epi-breeding in all kinds of crops. However, histone post-translational modifications are only relevant to epi-breeding in clonally propagated crops. Epigenomic variations such as DMRs related to disease resistance traits could be employed as molecular epigenomic markers to assist the evaluation and selection process. In addition, epigenetic modeling could be used to predict the effect of epigenetic variations on crop disease resistance and provide instruction for crop epi-breeding design. 


\section{CONCLUDING REMARKS AND PERSPECTIVES}

In this review, we highlighted the importance of epigenetic processes in the regulation of crop disease resistance, and discussed the potentials, challenges, and strategies of exploiting epigenetic variation for crop disease resistance improvement. Epigenetic processes such as DNA methylation, histone post-translational modifications, chromatin assembly and remodeling are highly interconnected and orchestrate plant transcriptional reprogramming in biotic and abiotic stress responses. In addition to modulating defense-related transcription essential for generational and transgenerational defense priming, epigenetic variations respond to pathogen infections and could be harnessed by pathogenic effectors, thereby increasing plant phenotypic plasticity and securing crop production under pathogen challenges.

As shown in Figure 1, both natural epigenetic diversity and epigenetic variations artificially induced by stress conditions, chemical treatments, mutations in epigenetic machinery, induced gene-specific DNA methylation and epigenome editing, could contribute to crop epi-breeding for disease resistance improvement. DNA methylation marks can be transgenerationally inherited and suitable for epi-breeding in all crops. However, information about histone post-translational modifications is likely to be erased during meiosis and only relevant to epi-breeding in clonally propagated crops. Since over $50 \%$ of seed-propagated crops can be clonally propagated, clonal propagation strategies such as root cutting, grafting, air layering, and tissue culture might provide a great

\section{REFERENCES}

Adachi, H., and Tsuda, K. (2019). Convergence of cell-surface and intracellular immune receptor signalling. New Phytol. 221, 1676-1678. doi: 10.1111/nph.15634

Akimoto, K., Katakami, H., Kim, H. J., Ogawa, E., Sano, C. M., Wada, Y., et al. (2007). Epigenetic inheritance in rice plants. Ann. Bot. 100, 205-217. doi: $10.1093 / \mathrm{aob} / \mathrm{mcm} 110$

Alonso, C., Ramos-Cruz, D., and Becker, C. (2019). The role of plant epigenetics in biotic interactions. New Phytol. 221, 731-737. doi: 10.1111/nph. 15408

Alvarez-Venegas, R., Abdallat, A. A., Guo, M., Alfano, J. R., and Avramova, Z. (2007). Epigenetic control of a transcription factor at the cross section of two antagonistic pathways. Epigenetics 2, 106-113. doi: 10.4161/epi.2.2.4404

Angel, A., Song, J., Dean, C., and Howard, M. (2011). A Polycomb-based switch underlying quantitative epigenetic memory. Nature 476, 105-108. doi: 10.1038/nature10241

Annacondia, M. L., Magerøy, M. H., and Martinez, G. (2018). Stress response regulation by epigenetic mechanisms: changing of the guards. Physiol. Plant 162, 239-250. doi: 10.1111/ppl.12662

Annacondia, M. L., Markovic, D., Reig-Valiente, J. L., Scaltsoyiannes, V., Pieterse, C., Ninkovic, V., et al. (2021). Aphid feeding induces the relaxation of epigenetic control and the associated regulation of the defense response in Arabidopsis. New Phytol. 230, 1185-1200. doi: 10.1111/nph.17226

Atighi, M. R., Verstraeten, B., De Meyer, T., and Kyndt, T. (2020). Genome-wide DNA hypomethylation shapes nematode pattern-triggered immunity in plants. New Phytol. 227, 545-558. doi: 10.1111/nph.16532 opportunity for the development of crop epi-breeding for disease resistance improvement. Epigenomic variations such as DMRs related to disease resistance traits could be employed as molecular epigenomic markers to assist the evaluation and selection processes. In addition, epigenetic modeling could be used to predict the effect of epigenetic variations on crop disease resistance and provide instruction for epigenetic engineering in crop resistance breeding. With the development of epigenetic methodology and theory on crop-pathogen interactions, exploiting epigenetic variations would provide new avenues for crop disease resistance improvement in the future.

\section{AUTHOR CONTRIBUTIONS}

PZ and CC wrote the manuscript. Both authors contributed to the article and approved the submitted version.

\section{FUNDING}

This work was funded by the National Natural Science Foundation of China (31701412), the Natural Science Foundation of Shandong Province (ZR2017BC109), and the Qingdao Science and Technology Bureau Fund (17-1-1-50-jch).

\section{ACKNOWLEDGMENTS}

We would like to thank Dr. Khalid Amari for the invitation to write this review. We are also grateful to two reviewers for their very helpful comments and suggestions on this and earlier versions.

Baubec, T., Pecinka, A., Rozhon, W., and Mittelsten Scheid, O. (2009). Effective, homogeneous and transient interference with cytosine methylation in plant genomic DNA by zebularine. Plant J. 57, 542-554. doi: 10.1111/j.1365-313X.2008.03699.x

Baulcombe, D. C., and Dean, C. (2014). Epigenetic regulation in plant responses to the environment. Cold Spring Harb. Perspect. Biol. 6:a019471. doi: 10.1101/cshperspect.a019471

Berr, A., McCallum, E. J., Alioua, A., Heintz, D., Heitz, T., and Shen, W. H. (2010). Arabidopsis histone methyltransferase SET DOMAIN GROUP8 mediates induction of the jasmonate/ethylene pathway genes in plant defense response to necrotrophic fungi. Plant Physiol. 154, 1403-1414. doi: 10.1104/pp.110.161497

Berriri, S., Gangappa, S. N., and Kumar, S. V. (2016). SWR1 chromatinremodeling complex subunits and H2A.Z have non-overlapping functions in immunity and gene regulation in Arabidopsis. Mol. Plant 9, 1051-1065. doi: 10.1016/j.molp.2016.04.003

Birkenbihl, R. P., Liu, S., and Somssich, I. E. (2017). Transcriptional events defining plant immune responses. Curr. Opin. Plant Biol. 38, 1-9. doi: 10.1016/j.pbi.2017.04.004

Bjornson, M., Pimprikar, P., Nürnberger, T., and Zipfel, C. (2021). The transcriptional landscape of Arabidopsis thaliana pattern-triggered immunity. Nat. Plants. doi: 10.1038/s41477-021-00874-5. [Epub ahead of print].

Black, J. C., Van Rechem, C., and Whetstine, J. R. (2012). Histone lysine methylation dynamics: establishment, regulation, and biological impact. Mol. Cell 48, 491-507. doi: 10.1016/j.molcel.2012. 11.006

Bruce, T. J. A. (2012). GM as a route for delivery of sustainable crop protection. J. Exp. Bot. 63, 537-541. doi: 10.1093/jxb/err281 
Buck-Sorlin, G. (2013). "Process-based model," in Encyclopedia of Systems Biology, eds W. Dubitzky, O. Wolkenhauer, and K. H. Cho, and H. Yokota (New York, NY: Springer), 135.

Chan, C., and Zimmerli, L. (2019). The histone demethylase IBM1 positively regulates Arabidopsis immunity by control of defense gene expression. Front. Plant Sci. 10:1587. doi: 10.3389/fpls.2019.01587

Chan, S. W.-L., Ian R Henderson, I. R., and Steven E Jacobsen, S. E. (2005). Gardening the genome: DNA methylation in Arabidopsis thaliana. Nat. Rev. Genet. 6, 351-360. doi: 10.1038/nrg1601

Chen, X., and Zhou, D. X. (2013). Rice epigenomics and epigenetics: challenges and opportunities. Curr. Opin. Plant Biol. 16, 164-169. doi: 10.1016/j.pbi.2013.03.004

Chen, Y., Wang, J., Yang, N., Wen, Z., Sun, X., Chai, Y., et al. (2018). Wheat microbiome bacteria can reduce virulence of a plant pathogenic fungus by altering histone acetylation. Nat. Commun. 9:3429. doi: 10.1038/s41467-018-05683-7

Choi, S. M., Song, H. R., Han, S. K., Han, M., Kim, C. Y., Park, J., et al. (2012). HDA19 is required for the repression of salicylic acid biosynthesis and salicylic acid-mediated defense responses in Arabidopsis. Plant J. 71, 135-146. doi: 10.1111/j.1365-313X.2012.04977.x

Clark, S. J., Harrison, J., Paul, C. L., and Frommer, M. (1994). High sensitivity mapping of methylated cytosines. Nucleic Acids Res. 22, 2990-2997. doi: $10.1093 /$ nar/22.15.2990

Cohen, S. P., and Leach, J. E. (2020). High temperature-induced plant disease susceptibility: more than the sum of its parts. Curr. Opin. Plant Biol. 56, 235-241. doi: 10.1016/j.pbi.2020.02.008

Colicchio, J. M., Miura, F., Kelly, J. K., Ito, T., and Hileman, L. C. (2015). DNA methylation and gene expression in Mimulus guttatus. BMC Genom. 16:507. doi: 10.1186/s12864-015-1668-0

Colot, V., and Rossignol, J. L. (1999). Eukaryotic DNA methylation as an evolutionary device. Bioessays 21, 402-411. doi: 10.1002/(SICI) 1521-1878(199905)21:5\&lt;402::AID-BIES7\&gt;3.0.CO;2-B

Coustham, V., Li, P., Strange, A., Lister, C., Song, J., and Dean, C. (2012). Quantitative modulation of polycomb silencing underlies natural variation in vernalization. Science 337, 584-587. doi: 10.1126/science.1221881

Couto, D., and Zipfel, C. (2016). Regulation of pattern recognition receptor signalling in plants. Nat. Rev. Immunol. 16, 537-552. doi: 10.1038/nri.2016.77

Cubas, P., Vincent, C., and Coen, E. (1999). An epigenetic mutation responsible for natural variation in floral symmetry. Nature 401, 157-161. doi: 10.1038/43657

Dalakouras, A., and Ganopoulos, I. (2021). Induction of promoter DNA methylation upon high-pressure spraying of double-stranded RNA in plants. Agronomy 11:789. doi: 10.3390/agronomy11040789

Dalakouras, A., and Papadopoulou, K. K. (2020). Epigenetic modifications: an unexplored facet of exogenous RNA application in plants. Plants 9:673. doi: $10.3390 /$ plants 9060673

Defraia, C. T., Wang, Y., Yao, J., and Mou, Z. (2013). Elongator subunit 3 positively regulates plant immunity through its histone acetyltransferase and radical S-adenosylmethionine domains. BMC Plant Biol. 13:102. doi: 10.1186/1471-2229-13-102

DeFraia, C. T., Zhang, X., and Mou, Z. (2010). Elongator subunit 2 is an accelerator of immune responses in Arabidopsis thaliana. Plant J. 64, 511-523. doi: 10.1111/j.1365-313X.2010.04345.x

Deng, Y., Zhai, K., Xie, Z., Yang, D., Zhu, X., Liu, J., et al. (2017). Epigenetic regulation of antagonistic receptors confers rice blast resistance with yield balance. Science 355, 962-965. doi: 10.1126/science.aai8898

Dhawan, R., Luo, H., Foerster, A. M., Abuqamar, S., Du, H. N., Briggs, S. D., et al. (2009). HISTONE MONOUBIQUITINATION1 interacts with a subunit of the mediator complex and regulates defense against necrotrophic fungal pathogens in Arabidopsis. Plant Cell 21, 1000-1019. doi: 10.1105/tpc.108.062364

Diezma-Navas, L., Pérez-González, A., Artaza, H., Alonso, L., Caro, E., Llave, C., et al. (2019). Crosstalk between epigenetic silencing and infection by tobacco rattle virus in Arabidopsis. Mol. Plant Pathol. 20, 1439-1452. doi: $10.1111 / \mathrm{mpp} .12850$

Ding, B., Bellizzi, M., Ning, Y., Meyers, B. C., and Wang, G. L. (2012). HDT701, a histone $\mathrm{H} 4$ deacetylase, negatively regulates plant innate immunity by modulating histone $\mathrm{H} 4$ acetylation of defense-related genes in rice. Plant Cell 24, 3783-3794. doi: 10.1105/tpc.112.101972
Ding, B., and Wang, G. L. (2015). Chromatin versus pathogens: the function of epigenetics in plant immunity. Front. Plant Sci. 6:675. doi: $10.3389 /$ fpls.2015.00675

Dowen, R. H., Pelizzola, M., Schmitz, R. J., Lister, R., Dowen, J. M., Nery, J. R., et al. (2012). Widespread dynamic DNA methylation in response to biotic stress. Proc. Natl. Acad. Sci. U.S.A. 109, E2183-E2191. doi: 10.1073/pnas.12093 29109

Dutta, A., Choudhary, P., Caruana, J., and Raina, R. (2017). JMJ27, an Arabidopsis H3K9 histone demethylase, modulates defense against Pseudomonas syringae and flowering time. Plant J. 91, 1015-1028. doi: 10.1111/tpj.13623

Elhamamsy, A. R. (2016). DNA methylation dynamics in plants and mammals: overview of regulation and dysregulation. Cell Biochem. Funct. 34, 289-298 doi: $10.1002 / \mathrm{cbf} .3183$

Erdmann, R. M., and Picard, C. L. (2020). RNA-directed DNA Methylation. PLoS Genet. 16:e1009034. doi: 10.1371/journal.pgen.1009034

Espinas, N. A., Saze, H., and Saijo, Y. (2016). Epigenetic control of defense signaling and priming in plants. Front. Plant Sci. 7:205. doi: $10.3389 /$ fpls.2016.01201

Feng, L., and Lou, J. (2019). DNA Methylation Analysis. Methods Mol. Biol. 1894, 181-227. doi: 10.1007/978-1-4939-8916-4_12

Gallusci, P., Dai, Z., Génard, M., Gauffretau, A., Leblanc-Fournier, N., Richard-Molard, C., et al. (2017). Epigenetics for plant improvement: current knowledge and modeling avenues. Trends Plant Sci. 22, 610-623. doi: 10.1016/j.tplants.2017.04.009

Geng, S., Kong, X., Song, G., Jia, M., Guan, J., Wang, F., et al. (2019). DNA methylation dynamics during the interaction of wheat progenitor Aegilops tauschii with the obligate biotrophic fungus Blumeria graminis f. sp. tritici. New Phytol. 221, 1023-1035. doi: 10.1111/nph.15432

Griffin, P. T., Niederhuth, C. E., and Schmitz, R. J. (2016). A comparative analysis of 5-azacytidine- and zebularine-induced DNA demethylation. G3 6, 2773-2780. doi: 10.1534/g3.116.030262

Guevara, M. Á., de María, N., Sáez-Laguna, E., Vélez, M. D., Cervera, M. T., and Cabezas, J. A. (2017). Analysis of DNA cytosine methylation patterns using methylation-sensitive amplification polymorphism (MSAP). Methods Mol. Biol. 1456, 99-112. doi: 10.1007/978-1-4899-7708-3_9

He, M., Xu, Y., Chen, J., Luo, Y., Lv, Y., Su, J., et al. (2018). MoSnt2dependent deacetylation of histone $\mathrm{H} 3$ mediates MoTor-dependent autophagy and plant infection by the rice blast fungus Magnaporthe oryzae. Autophagy 14, 1543-1561. doi: 10.1080/15548627.2018.1458171

He, Y., and Li, Z. (2018). Epigenetic environmental memories in plants: establishment, maintenance, and reprogramming. Trends Genet. 34, 856-866. doi: $10.1016 /$ j.tig.2018.07.006

Henderson, I. R., and Jacobsen, S. E. (2007). Epigenetic inheritance in plants. Nature 447, 418-424. doi: 10.1038/nature05917

Hilton, I. B., D'Ippolito, A. M., Vockley, C. M., Thakore, P. I., Crawford, G. E., Reddy, T. E., et al. (2015). Epigenome editing by a CRISPR-Cas9based acetyltransferase activates genes from promoters and enhancers. Nat. Biotechnol. 33, 510-517. doi: 10.1038/nbt.3199

Hou, Y., Wang, L., Wang, L., Liu, L., Li, L., Sun, L., et al. (2015). JMJ704 positively regulates rice defense response against Xanthomonas oryzae pv. oryzae infection via reducing $\mathrm{H} 3 \mathrm{~K} 4 \mathrm{me} 2 / 3$ associated with negative disease resistance regulators. BMC Plant Biol. 15:286. doi: 10.1186/s12870-0150674-3

Hsu, H. K., Weng, Y. I., Hsu, P. Y., Huang, T. H., and Huang, Y. W. (2020). Detection of DNA methylation by MeDIP and MBDCap assays: an overview of techniques. Methods Mol. Biol. 2102, 225-234. doi: 10.1007/978-1-0716-0223-2_12

Hu, M., Pei, B. L., Zhang, L. F., and Li, Y. Z. (2014). Histone H2B monoubiquitination is involved in regulating the dynamics of microtubules during the defense response to Verticillium dahliae toxins in Arabidopsis. Plant Physiol. 164, 1857-1865. doi: 10.1104/pp.113.234567

Hu, Y., Morota, G., Rosa, G. J., and Gianola, D. (2015). Prediction of plant height in Arabidopsis thaliana using DNA methylation data. Genetics 201, 779-793. doi: 10.1534/genetics.115.177204

Huang, C. Y., Rangel, D. S., Qin, X., Bui, C., Li, R., Jia, Z., et al. (2021). The chromatin-remodeling protein BAF60/SWP73A regulates the plant immune receptor NLRs. Cell Host Microbe 29, 425-434. doi: 10.1016/j.chom.2021.01.005 
Imhof, A., and Wolffe, A. P. (1998). Transcription: gene control by targeted histone acetylation. Curr. Biol. 8, R422-R424. doi: 10.1016/S0960-9822(98) 70268-4

Iwasaki, M., and Paszkowski, J. (2014). Epigenetic memory in plants. EMBO J. 33, 1987-1998. doi: 10.15252/embj.201488883

Jaskiewicz, M., Conrath, U., and Peterhänsel, C. (2011). Chromatin modification acts as a memory for systemic acquired resistance in the plant stress response. EMBO Rep. 12, 50-55. doi: 10.1038/embor.2010.186

Jin, P., Gao, S., He, L., Xu, M., Zhang, T., Zhang, F., et al. (2020). Genomewide identification and expression analysis of the histone deacetylase gene family in wheat (Triticum aestivum L.). Plants 10:19. doi: 10.3390/plants100 10019

Johnson, K. C., Xia, S., Feng, X., and Li, X. (2015). The chromatin remodeler SPLAYED negatively regulates SNC1-mediated immunity. Plant Cell Physiol. 56, 1616-1623. doi: 10.1093/pcp/pcv087

Johnson, L. M., Du, J., Hale, C. J., Bischof, S., Feng, S., Chodavarapu, R. K., et al. (2014). SRA- and SET-domain-containing proteins link RNA polymerase V occupancy to DNA methylation. Nature 507, 124-128. doi: 10.1038/nature12931

Jones, J. D. G., Vance, R. E., and Dangl, J. L. (2016). Intracellular innate immune surveillance devices in plants and animals. Science 354:6316. doi: 10.1126/science.aaf6395

Kapazoglou, A., Ganopoulos, I., Tani, E., and Tsaftaris, A. (2018). Epigenetics, epigenomics and crop improvement. Adv. Bot. Res. 86, 287-324. doi: 10.1016/bs.abr.2017.11.007

Kasai, M., and Kanazawa, A. (2013). Induction of RNA-directed DNA methylation and heritable transcriptional gene silencing as a tool to engineer novel traits in plants. Plant Biotechnol. 30, 233-241. doi: 10.5511/plantbiotechnology.13.0319a

Kearns, N. A., Pham, H., Tabak, B., Genga, R. M., Silverstein, N. J., Garber, M., et al. (2015). Functional annotation of native enhancers with a Cas9-histone demethylase fusion. Nat. Methods 12, 401-403. doi: 10.1038/nmeth.3325

Kellenberger, R. T., Schlüter, P. M., and Schiestl, F. P. (2016). Herbivore-induced DNA demethylation changes floral signalling and attractiveness to pollinators in Brassica rapa. PLoS ONE 11:e0166646. doi: 10.1371/journal.pone.0166646

Kim, K. C., Lai, Z., Fan, B., and Chen, Z. (2008). Arabidopsis WRKY38 and WRKY62 transcription factors interact with histone deacetylase 19 in basal defense. Plant Cell 20, 2357-2371. doi: 10.1105/tpc.107.055566

Kolb, A. F., Coates, C. J., Kaminski, J. M., Summers, J. B., Miller, A. D., and Segal, D. J. (2005). Site-directed genome modification: nucleic acid and protein modules for targeted integration and gene correction. Trends Biotechnol. 23, 399-406. doi: 10.1016/j.tibtech.2005.06.005

Kong, L., Liu, Y., Wang, X., and Chang, C. (2020a). Insight into the role of epigenetic processes in abiotic and biotic stress response in wheat and barley. Int. J. Mol. Sci. 21:1480. doi: 10.3390/ijms21041480

Kong, L., Qiu, X., Kang, J., Wang, Y., Chen, H., Huang, J., et al. (2017). A Phytophthora Effector manipulates host histone acetylation and reprograms defense gene expression to promote infection. Curr. Biol. 27, 981-991. doi: 10.1016/j.cub.2017.02.044

Kong, L., Zhi, P., Liu, J., Li, H., Zhang, X., Xu, J., et al. (2020b). Epigenetic activation of Enoyl-CoA Reductase by an acetyltransferase complex triggers wheat wax biosynthesis. Plant Physiol. 183, 1250-1267. doi: 10.1104/pp.20. 00603

Kungulovski, G., and Jeltsch, A. (2016). Epigenome editing: state of the art, concepts, and perspectives. Trends Genet. 32, 101-113. doi: 10.1016/j.tig.2015.12.001

Lämke, J., and Bäurle, I. (2017). Epigenetic and chromatin-based mechanisms in environmental stress adaptation and stress memory in plants. Genome Biol. 18:124. doi: 10.1186/s13059-017-1263-6

Latrasse, D., Jégu, T., Li, H., de Zelicourt, A., Raynaud, C., Legras, S., et al. (2017). MAPK-triggered chromatin reprogramming by histone deacetylase in plant innate immunity. Genome Biol. 18:131. doi: 10.1186/s13059-0171261-8

Latutrie, M., Gourcilleau, D., and Pujol, B. (2019). Epigenetic variation for agronomic improvement: an opportunity for vegetatively propagated crops. Am. J. Bot. 106, 1281-1284. doi: 10.1002/ajb2.1357

Laura, B., Silvia, P., Francesca, F., Benedetta, S., and Carla, C. (2018). Epigenetic control of defense genes following MeJA-induced priming in rice (O. sativa). J. Plant Physiol. 228, 166-177. doi: 10.1016/j.jplph.2018. 06.007

Law, J. A., and Jacobsen, S. E. (2010). Establishing, maintaining and modifying DNA methylation patterns in plants and animals. Nat. Rev. Genet. 11, 204-220. doi: $10.1038 / \operatorname{nrg} 2719$

Lee, S., Fu, F., Xu, S., Lee, S. Y., Yun, D. J., and Mengiste, T. (2016). Global regulation of plant immunity by histone lysine methyl transferases. Plant Cell 28, 1640-1661. doi: 10.1105/tpc.16.00012

Leonetti, P., and Molinari, S. (2020). Epigenetic and metabolic changes in root-knot nematode-plant interactions. Int. J. Mol. Sci. 21:7759. doi: 10.3390/ijms21207759

Li, B., Carey, M., and Workman, J. L. (2007). The role of chromatin during transcription. Cell 128, 707-719. doi: 10.1016/j.cell.2007.01.015

Li, L., Yu, Y., Zhou, Z., and Zhou, J. M. (2016). Plant pattern-recognition receptors controlling innate immunity. Sci. China Life Sci. 59, 878-888. doi: 10.1007/s11427-016-0115-2

Li, Q., Hermanson, P. J., and Springer, N. M. (2018). Detection of DNA methylation by whole-genome bisulfite sequencing. Methods Mol. Biol. 1676, 185-196. doi: 10.1007/978-1-4939-7315-6_11

Li, Q., Song, J., West, P. T., Zynda, G., Eichten, S. R., Vaughn, M. W., et al. (2015). Examining the causes and consequences of context-specific differential DNA methylation in maize. Plant Physiol. 168, 1262-1274. doi: 10.1104/pp.15.00052

Li, W., Xiong, Y., Lai, L. B., Zhang, K., Li, Z., Kang, H., et al. (2021). The rice RNase P protein subunit Rpp30 confers broad-spectrum resistance to fungal and bacterial pathogens. Plant Biotechnol. J. doi: 10.1111/pbi.13612

Li, X., Jiang, Y., Ji, Z., Liu, Y., and Zhang, Q. (2015). BRHIS1 suppresses rice innate immunity through binding to monoubiquitinated $\mathrm{H} 2 \mathrm{~A}$ and $\mathrm{H} 2 \mathrm{~B}$ variants. EMBO Rep. 16, 1192-1202. doi: 10.15252/embr.201440000

Li, Y., Xia, Q., Kou, H., Wang, D., Lin, X., Wu, Y., et al. (2011). Induced Pib expression and resistance to Magnaporthe grisea are compromised by cytosine demethylation at critical promoter regions in rice. J. Integr. Plant Biol. 53, 814-823. doi: 10.1111/j.1744-7909.2011.01070.x

Liu, C., and Moschou, P. N. (2018). Phenotypic novelty by CRISPR in plants. Dev. Biol. 435, 170-175. doi: 10.1016/j.ydbio.2018.01.015

Liu, J., Zhi, P., Wang, X., Fan, Q., and Chang, C. (2019). Wheat WD40-repeat protein TaHOS15 functions in a histone deacetylase complex to fine-tune defense responses to Blumeria graminis f.sp. tritici. J. Exp. Bot. 70, 255-268. doi: 10.1093/jxb/ery330

Liu, R., How-Kit, A., Stammitti, L., Teyssier, E., Rolin, D., MortainBertrand, A., et al. (2015). A DEMETER-like DNA demethylase governs tomato fruit ripening. Proc. Natl. Acad. Sci. U.S.A. 112, 10804-10809. doi: $10.1073 /$ pnas. 1503362112

Long, Y., Xia, W., Li, R., Wang, J., Shao, M., Feng, J., et al. (2011). Epigenetic QTL mapping in Brassica napus. Genetics 189, 1093-1102. doi: 10.1534/genetics.111.131615

López Sánchez, A., Stassen, J. H., Furci, L., Smith, L. M., and Ton, J. (2016). The role of DNA (de)methylation in immune responsiveness of Arabidopsis. Plant J. 88, 361-374. doi: 10.1111/tpj.13252

Luna, E., Bruce, T. J., Roberts, M. R., Flors, V., and Ton, J. (2012). Next-generation systemic acquired resistance. Plant Physiol. 158, 844-853. doi: 10.1104/pp.111.187468

Manning, K., Tör, M., Poole, M., Hong, Y., Thompson, A. J., and King, G. J. (2006). A naturally occurring epigenetic mutation in a gene encoding an SBP-box transcription factor inhibits tomato fruit ripening. Nature Genet. 38, 948-952. doi: $10.1038 / \mathrm{ng} 1841$

Martin, A., Troadec, C., Boualem, A., Rajab, M., Fernandez, R., Morin, H., et al. (2009). A transposon-induced epigenetic change leads to sex determination in melon. Nature 461, 1135-1138. doi: 10.1038/nature08498

Mauch-Mani, B., Baccelli, I., Luna, E., and Flors, V. (2017). Defense priming: an adaptive part of induced resistance. Annu. Rev. Plant Biol. 68, 485-512. doi: 10.1146/annurev-arplant-042916-041132

Meller, B., Kuznicki, D., Arasimowicz-Jelonek, M., Deckert, J., and FloryszakWieczorek, J. (2018). BABA-primed histone modifications in potato for intergenerational resistance to Phytophthora infestans. Front. Plant Sci. 9:1228. doi: 10.3389/fpls.2018.01228

Metje-Sprink, J., Menz, J., Modrzejewski, D., and Sprink, T. (2019). DNAfree genome editing: past, present and future. Front. Plant Sci. 9:1957. doi: $10.3389 /$ fpls.2018.01957 
Meyer, R. S., DuVal, A. E., and Jensen, H. R. (2012). Patterns and processes in crop domestication: an historical review and quantitative analysis of 203 global food crops. New Phytol. 196, 29-48. doi: 10.1111/j.1469-8137.2012.04253.x

Mirouze, M., and Paszkowski, J. (2011). Epigenetic contribution to stress adaptation in plants. Curr. Opin. Plant Biol. 14, 267-274. doi: 10.1016/j.pbi.2011.03.004

Mozgová, I., Wildhaber, T., Liu, Q., Abou-Mansour, E., L'Haridon, F., Métraux, J. P., et al. (2015). Chromatin assembly factor CAF-1 represses priming of plant defence response genes. Nat. Plants 1:15127. doi: 10.1038/nplants. 2015.127

Muñoz-Viana, R., Wildhaber, T., Trejo-Arellano, M. S., Mozgov,á, I., and Hennig, L. (2017). Arabidopsis chromatin assembly factor 1 is required for occupancy and position of a subset of nucleosomes. Plant J. 92, 363-374. doi: $10.1111 /$ tpj. 13658

Ngom, B., Sarr, I., Kimatu, J., Mamati, E., and Kane, N. A. (2017). Genomewide analysis of cytosine DNA methylation revealed salicylic acid promotes defense pathways over seedling development in pearl millet. Plant Signal. Behav. 12:e1356967. doi: 10.1080/15592324.2017.1356967

Ngou, B. P. M., Ahn, H. K., Ding, P., and Jones, J. D. G. (2021). Mutual potentiation of plant immunity by cell-surface and intracellular receptors. Nature 592, 110-115. doi: 10.1038/s41586-021-03315-7

Nicaise, V. (2017). Boosting innate immunity to sustainably control diseases in crops. Curr. Opin. Virol. 26, 112-119. doi: 10.1016/j.coviro.2017.07.030

Oliva, R., and Quibod, I. L. (2017). Immunity and starvation: New opportunities to elevate disease resistance in crops. Curr. Opin. Plant Biol. 38, 84-91. doi: 10.1016/j.pbi.2017.04.020

Pruitt, R. N., Gust, A. A., and Nürnberger, T. (2021). Plant immunity unified. Nat. Plants. 7, 382-383. doi: 10.1038/s41477-021-00903-3

Rambani, A., Rice, J. H., Liu, J., Lane, T., Ranjan, P., Mazarei, M., et al. (2015). The methylome of soybean roots during the compatible interaction with the soybean cyst nematode. Plant Physiol. 168, 1364-1377. doi: 10.1104/pp.15.00826

Ramírez-Carrasco, G., Martínez-Aguilar, K., and Alvarez-Venegas, R. (2017). Transgenerational defense priming for crop protection against plant pathogens: a hypothesis. Front. Plant Sci. 8:696. doi: 10.3389/fpls.2017.00696

Ramirez-Prado, J. S., Abulfaraj, A. A., Rayapuram, N., Benhamed, M., and Hirt, H. (2018a). Plant immunity: from signaling to epigenetic control of defense. Trends Plant Sci. 23, 833-844. doi: 10.1016/j.tplants.2018.06.004

Ramirez-Prado, J. S., Piquerez, S. J. M., Bendahmane, A., Hirt, H., Raynaud, C., and Benhamed, M. (2018b). Modify the histone to win the battle: chromatin dynamics in plant-pathogen interactions. Front. Plant Sci. 9:355. doi: $10.3389 /$ fpls.2018.00355

Reimer-Michalski, E. M., and Conrath, U. (2016). Innate immune memory in plants. Semin Immunol. 28, 319-327. doi: 10.1016/j.smim.2016.05.006

Richards, D., Berry, S., and Howard, M. (2012). Illustrations of mathematical modeling in biology: epigenetics, meiosis, and an outlook. Cold Spring Harb. Symp. Quant. Biol. 77, 175-181. doi: 10.1101/sqb.2013.77.015941

Rodriguez-Moreno, L., Song, Y., and Thomma, B. P. (2017). Transfer and engineering of immune receptors to improve recognition capacities in crops. Curr. Opin. Plant Biol. 38, 42-49. doi: 10.1016/j.pbi.2017.04.010

Saijo, Y., Loo, E. P., and Yasuda, S. (2018). Pattern recognition receptors and signaling in plant-microbe interactions. Plant J. 93, 592-613. doi: $10.1111 /$ tpj. 13808

Schmitz, R. J., He, Y., Valdés-López, O., Khan, S. M., Joshi, T., Urich, M. A., et al. (2013). Epigenome-wide inheritance of cytosine methylation variants in a recombinant inbred population. Genome Res. 23, 1663-1674. doi: $10.1101 /$ gr. 152538.112

Sharrock, J., and Sun, J. C. (2020). Innate immunological memory: from plants to animals. Curr. Opin. Immunol. 62, 69-78. doi: 10.1016/j.coi.2019.12.001

Silva, M. S., Arraes, F. B. M., Campos, M. A., Grossi-de-Sa, M., Fernandez, D., Cândido, E. S., et al. (2018). Review: Potential biotechnological assets related to plant immunity modulation applicable in engineering disease-resistant crops. Plant Sci. 270, 72-84. doi: 10.1016/j.plantsci.2018.02.013

Slaughter, A., Daniel, X., Flors, V., Luna, E., Hohn, B., and Mauch-Mani, B. (2012). Descendants of primed Arabidopsis plants exhibit resistance to biotic stress. Plant Physiol. 158, 835-843. doi: 10.1104/pp.111.191593

Song, G., and Walley, J. W. (2016). Dynamic protein acetylation in plant-pathogen interactions. Front. Plant Sci. 7:421. doi: 10.3389/fpls.2016.00421
Springer, N. M., and Schmitz, R. J. (2017). Exploiting induced and natural epigenetic variation for crop improvement. Nat. Rev. Genet. 18, 563-575. doi: 10.1038/nrg.2017.45

Stassen, J., López, A., Jain, R., Pascual-Pardo, D., Luna, E., Smith, L. M., et al. (2018). The relationship between transgenerational acquired resistance and global DNA methylation in Arabidopsis. Sci. Rep. 8:14761. doi: 10.1038/s41598-018-32448-5

Sun, Y., Fan, M., and He, Y. (2019). DNA methylation analysis of the Citrullus lanatus response to cucumber green mottle mosaic virus infection by wholegenome bisulfite sequencing. Genes 10:344. doi: 10.3390/genes10050344

Telias, A., Lin-Wang, K., Stevenson, D. E., Cooney, J. M., Hellens, R. P., Allan, A. C., et al. (2011). Apple skin patterning is associated with differential expression of MYB10. BMC Plant Biol. 11:93. doi: 10.1186/1471-2229-11-93

Tirnaz, S., and Batley, J. (2019). Epigenetics: potentials and challenges in crop breeding. Mol. Plant 12, 1309-1311. doi: 10.1016/j.molp.2019. 09.006

Tirnaz, S., and Jacqueline, I. (2019). DNA methylation: toward crop disease resistance improvement. Trends Plant Sci. 24, 1137-1150. doi: $10.1016 /$ j.tplants.2019.08.007

van der Burgh, A. M., and Joosten, M. H. A. J. (2019). Plant immunity: Thinking outside and inside the box. Trends Plant Sci. 24, 587-601. doi: 10.1016/j.tplants.2019.04.009

Varotto, S., Tani, E., Abraham, E., Krugman, T., Kapazoglou, A., Melzer, R., et al. (2020). Epigenetics: possible applications in climate-smart crop breeding. J. Exp. Bot. 71, 5223-5236. doi: 10.1093/jxb/eraa188

Vojta, A., Dobrini,ć, P., Tadi,ć, V., Bočkor, L., Korać, P., Julg, B., et al. (2016). Repurposing the CRISPR-Cas9 system for targeted DNA methylation. Nucleic Acids Res. 44, 5615-5628. doi: 10.1093/nar/gkw159

Walker, J., Zhang, J., Liu, Y., Vickers, M., Dolan, L., Nakajima, K., et al. (2021). Extensive N4 cytosine methylation is essential for Marchantia sperm function. bioRxiv. doi: 10.1101/2021.02.12.428880. [Epub ahead of print].

Walley, J. W., Rowe, H. C., Xiao, Y., Chehab, E. W., Kliebenstein, D. J., Wagner, D., et al. (2008). The chromatin remodeler SPLAYED regulates specific stress signaling pathways. PLoS Pathog. 4:e1000237. doi: 10.1371/journal.ppat.1000237

Walley, J. W., Shen, Z., McReynolds, M. R., Schmelz, E. A., and Briggs, S. P. (2018). Fungal-induced protein hyperacetylation in maize identified by acetylome profiling. Proc. Natl. Acad. Sci. U.S.A. 115, 210-215. doi: 10.1073/pnas.1717519115

Wang, B., Yang, X., Wang, Y., Xie, Y., and Zhou, X. (2018). Tomato yellow leaf curl virus V2 interacts with host Histone Deacetylase 6 to suppress methylationmediated transcriptional gene silencing in plants. J. Virol. 92, e00036-e00018. doi: 10.1128/JVI.00036-18

Wang, C., Ding, Y., Yao, J., Zhang, Y., Sun, Y., Colee, J., et al. (2015). Arabidopsis Elongator subunit 2 positively contributes to resistance to the necrotrophic fungal pathogens Botrytis cinerea and Alternaria brassicicola. Plant J. 83, 1019-1033. doi: $10.1111 /$ tpj.12946

Wang, C., Gao, F., Wu, J., Dai, J., Wei, C., and Li, Y. (2010). Arabidopsis putative deacetylase AtSRT2 regulates basal defense by suppressing PAD4, EDS5 and SID2 expression. Plant Cell Physiol. 51, 1291-1299. doi: 10.1093/pcp/pcq087

Wang, C., Wang, C., Xu, W., Zou, J., Qiu, Y., Kong, J., et al. (2018). Epigenetic changes in the regulation of Nicotiana tabacum response to cucumber mosaic virus infection and symptom recovery through single-base resolution methylomes. Viruses 10:402. doi: 10.3390/v10080402

Wang, C., Wang, C., Zou, J., Yang, Y., Li, Z., and Zhu, S. (2019). Epigenetics in the plant-virus interaction. Plant Cell Rep. 38, 1031-1038. doi: 10.1007/s00299-019-02414-0

Wang, X., Zhi, P., Fan, Q., Zhang, M., and Chang, C. (2019). Wheat CHD3 protein TaCHR729 regulates the cuticular wax biosynthesis required for stimulating germination of Blumeria graminis f.sp. tritici. J. Exp. Bot. 70, 701-713. doi: $10.1093 / \mathrm{jxb} / \mathrm{ery} 377$

Wang, Y., Hu, Q., Wu, Z., Wang, H., Han, S., Jin, Y., et al. (2017). HISTONE DEACETYLASE 6 represses pathogen defence responses in Arabidopsis thaliana. Plant Cell Environ. 40, 2972-2986. doi: 10.1111/ pce. 13047

Woo, J. W., Kim, J., Kwon, S. I., Corvalán, C., Cho, S. W., Kim, H., et al. (2015). DNA-free genome editing in plants with preassembled CRISPR-Cas9 ribonucleoproteins. Nat. Biotechnol. 33, 1162-1164. doi: 10.1038/nbt.3389 
Yang, S., Tang, F., Caixeta, E. T., and Zhu, H. (2013). Epigenetic regulation of a powdery mildew resistance gene in Medicago truncatula. Mol. Plant 6, 2000-2003. doi: 10.1093/mp/sst106

Yang, X., Lu, Y., Zhao, X., Jiang, L., Xu, S., Peng, J., et al. (2019). Downregulation of nuclear protein $\mathrm{H} 2 \mathrm{~B}$ induces salicylic acid mediated defense against PVX infection in Nicotiana benthamiana. Front. Microbiol. 10:1000. doi: $10.3389 /$ fmicb. 2019.01000

Yu, A., Lepère, G., Jay, F., Wang, J., Bapaume, L., Wang, Y., et al. (2013). Dynamics and biological relevance of DNA demethylation in Arabidopsis antibacterial defense. Proc. Natl. Acad. Sci. U.S.A. 110, 2389-2394. doi: $10.1073 /$ pnas. 1211757110

Yu, X., Feng, B., He, P., and Shan, L. (2017). From chaos to harmony: Responses and signaling upon microbial pattern recognition. Annu. Rev. Phytopathol. 55, 109-137. doi: 10.1146/annurev-phyto-080516-035649

Yuan, M., Jiang, Z., Bi, G., Nomura, K., Liu, M., Wang, Y., et al. (2021). Patternrecognition receptors are required for NLR-mediated plant immunity. Nature 592, 105-109. doi: 10.1038/s41586-021-03316-6

Zhang, H., Tao, Z., Hong, H., Chen, Z., Wu, C., Li, X., et al. (2016). Transposonderived small RNA is responsible for modified function of WRKY45 locus. Nat. Plants 2:16016. doi: 10.1038/nplants.2016.16

Zhang, X., Ménard, R., Li, Y., Coruzzi, G. M., Heitz, T., Shen, W. H., et al. (2020). Arabidopsis SDG8 potentiates the sustainable transcriptional induction of the pathogenesis-related genes $P R 1$ and $P R 2$ during plant defense response. Front. Plant Sci. 11:277. doi: 10.3389/fpls.2020.00277

Zhang, Y. Y., Latzel, V., Fischer, M., and Bossdorf, O. (2018). Understanding the evolutionary potential of epigenetic variation: a comparison of heritable phenotypic variation in epiRILs, RILs, and natural ecotypes of Arabidopsis thaliana. Heredity 121, 257-265. doi: 10.1038/s41437-018-0095-9

Zhao, J., Chen, Q., Zhou, S., Sun, Y., Li, X., and Li, Y. (2020). H2Bub1 regulates rbohd-dependent hydrogen peroxide signal pathway in the defense responses to Verticillium dahliae toxins. Plant Physiol. 182, 640-657. doi: 10.1104/pp.19.00913

Zhi, P., Kong, L., Liu, J., Zhang, X., Wang, X., Li, H., et al. (2020). Histone deacetylase TaHDT701 functions in TaHDA6-TaHOS15 Complex to regulate wheat defense responses to Blumeria graminis f.sp. tritici. Int. J. Mol. Sci. 21:2640. doi: 10.3390/ijms21072640

Zhou, J. M., and Zhang, Y. (2020). Plant immunity: danger perception and signaling. Cell 181, 978-989. doi: 10.1016/j.cell.2020.04.028

Zhu, Q. H., Shan, W. X., Ayliffe, M. A., and Wang, M. B. (2016). Epigenetic mechanisms: an emerging player in plant-microbe interactions. Mol. Plant Microbe Interact. 29, 187-196. doi: 10.1094/MPMI-08-15-0194-FI

Zou, B., Yang, D. L., Shi, Z., Dong, H., and Hua, J. (2014). Monoubiquitination of histone $2 \mathrm{~B}$ at the disease resistance gene locus regulates its expression and impacts immune responses in Arabidopsis. Plant Physiol. 65, 309-318. doi: 10.1104/pp.113.227801

Zytynska, S. E., Eicher, M., Rothballer, M., and Weisser, W. W. (2020). Microbial- mediated plant growth promotion and pest suppression varies under climate change. Front. Plant Sci. 11:573578. doi: 10.3389/fpls.2020. 573578

Conflict of Interest: The authors declare that the research was conducted in the absence of any commercial or financial relationships that could be construed as a potential conflict of interest.

Copyright (c) 2021 Zhi and Chang. This is an open-access article distributed under the terms of the Creative Commons Attribution License (CC BY). The use, distribution or reproduction in other forums is permitted, provided the original author(s) and the copyright owner(s) are credited and that the original publication in this journal is cited, in accordance with accepted academic practice. No use, distribution or reproduction is permitted which does not comply with these terms. 